The Missing Dimension 


\title{
THE MISSING DIMENSION
}

Governments and Intelligence Communities in the Twentieth Century

\author{
Edited by \\ CHRISTOPHER ANDREW \\ and \\ DAVID DILKS
}

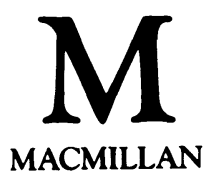


(C) Christopher Andrew, Robert Cecil, David Dilks,

David Kahn, Ian Nish, Eunan O'Halpin,

Alasdair Palmer, Harry Howe Ransom, Jürgen Rohwer,

Jean Stengers, Wesley K. Wark 1984

Softcover reprint of the hardcover 1st edition 1984

All rights reserved. No part of this publication may be reproduced or transmitted, in any form or by any means, without permission

First published 1984 by

Higher and Further Education Division

MACMILLAN PUBLISHERS LTD

London and Basingstoke

Companies and representatives

throughout the world

Typeset by

Wessex Typesetters Ltd

Frome, Somerset

Printed in Great Britain by

Camelot Press Ltd. Southampton

British Library Cataloguing in Publication Data

The missing dimension: governments and intelligence communities in the twentieth century

1. Secret service-History

I. Andrew, Christopher

327.1'2'0904

II. Dilks, David

HV7961

ISBN 978-1-349-07236-1

ISBN 978-1-349-07234-7 (eBook)

DOI 10.1007/978-1-349-07234-7 


\section{Contents}

\section{Introduction}

CHRISTOPHER ANDREW and DAVID DILKS

1 JAPANESE INTELLIGENCE AND THE APPROACH OF THE RUSSO-JAPANESE WAR

IA N NISH

2 CODEBREAKERS AND FOREIGN OFFICES: THE FRENCH, BRITISH AND AMERICAN EXPERIENCE CHRISTOPHER ANDREW

3 BRITISH INTELLIGENCE IN IRELAND, 1914-1921 EUNAN O'HALPIN

4 BRITISH MILITARY AND ECONOMIC INTELLIGENCE: ASSESSMENTS OF NAZI GERMANY BEFORE THE SECOND WORLD WAR WESLEY K. WARK

5 FLASHES OF INTELLIGENCE: THE FOREIGN OFFICE, THE SIS AND SECURITY BEFORE THE SECOND WORLD WAR

DAVID DILKS

6 ENIGMA, THE FRENCH, THE POLES AND THE BRITISH, 1931-1940

JEAN STENGERS

7 CODEBREAKING IN WORLD WARS I AND II: THE MAJOR SUCGESSES AND FAILURES, THEIR CAUSES AND THEIR EFFEGTS

DAVID KAHN

8 RADIO INTELLIGENCE AND ITS ROLE IN THE BATTLE OF THE ATLANTIC

JÜRGEN ROHWER

9 THE CAMBRIDGE COMINTERN 
10 SECRET INTELLIGENCE IN THE UNITED STATES, 1947-1982: THE CIA'S SEARCH FOR LEGITIMACY 199 HARRY HOWE RANSOM 11 THE HISTORY OF THE D-NOTICE COMMITTEE 227 ALASDAIR PALMER

Notes and References 250

Notes on the Contributors 286

Index 287 